\title{
Some Biochemical and Haematological Studies on the Effect of Black seed and Curcumin in Vaccinated Broiler with Gumboro
}

\author{
Azza A.Hassan ${ }^{1}$, Ghada A. Abd El-Diem² \\ ${ }^{1}$ Biochemistry, Nutritional Deficiency and Toxicology Department, Animal Health Research Institute- Mansoura Lab, Egypt \\ ${ }^{2}$ Poultry Diseases Department, Animal Health Research Institute- Mansoura Lab, Egypt
}

\begin{abstract}
This study was carried out to investigate the adverse effects of Gumborovaccine on performances, immunity and some biochemical parmeter of Broiler chicks. A total 120 broiler chicks were used in this study and divided into 6 groups each group contain 20 chicken and all chicks were weighted weekly till the end of the experiment. The results showed the broiler treated with Nigella sativa and curcumin produce increase in B.W, TLC andlymophcyte while decrease in neutrophil percent. Nigella sativa and curcumin induced increase in TP, Albumin, although NS and curcumin groups showed a significance decrease in ALT and AST, significantly increase in SOD, GSH, CAT and significantly decrease in MDA. Gumboro vaccine induced hepatic disorders and immunosuppressive revealed by decrease $B . W$, total Leucocytic countand lymophcyte percent, while increase in neutrophil percent. Gumboro vaccine induced decrease in total protein, Albumin, globulin increase in alanine aminotransferase (ALT) and Aspartate aminotransferase (AST), decrease in SOD, GSH, CAT, and significantly increase in MDA. This study indicated that treatment with Nigella sativa and Curcumin improved the adverse effects of Gumboro vaccine on performances, immunity, some biochemical parameters in serum and tissues, also decrease the risk of exposure to Gumboro vaccine, improve both of general health condition and immunostatus of chicks.
\end{abstract}

Keywords: Black seed,Curcumin, Broiler, Gumboro vaccine

\section{Introduction}

Gumboro Disease (GD) called Infectious Bursal Disease (IBD) is a highly contagious viral disease, it was first recogenized in Gumboro district of Delware , USA (Cosgrove 1962). In Egypt ,IBD was reported for first time by El-Sergany et al., (1974) Later on many outbreak were reported and described in various governorates with severe pathological lesions and high mortality up to $70 \%$ (Madbouly et al.,1992 ). One of the most critical disease is Gumboro which is the most important second viral disease after Newcastle . (Abdel-Rahman et al.,2007).

Medicinal plants are widely used as home remedies and raw materials for the pharmaceutical industries. Herbal remedies are used in the prevention, treatment and cure of disorders and diseases since ancient times (Ashiq,et al., 2014). Nigella sativa is an annual herbaceous plant; seeds are black in color and taste slightly bitter. They are frequently used as a spice and added as a flavoring agent to bread, pickles and other dishes (Aljabre et al., 2005). The seeds of the plant are extensively used in traditional medicine in some countries, for the treatment of several diseases (Nostro et al., 2000). Recent scientific investigations on the seeds and their oil indicated a number of pharmacological activities including anti-carcinogenic (Rooney and Ryan, 2005), anti-ulcer (Kanter et al., 2005), anti-bacterial (Morsi, 2000), antifungal (Khan et al., 2003), anti-inflammatory, anti-pyretic and analgesic (Al-Ghamdi, 2001).Curcumin (1,7-Bis 4hydroxy-3-methoxy phenyl)-1-6- heptadiene-3,5-dione) , which gives the yellow colour to turmeric, was first isolated in 1815, and its structure as diferuloylmethane was determined in 1910 by Kazimierz Kostanecki, J. Miłobędzka and Wiktor Lampe (Shishodia et al., 2005).Turmeric, Curcuma longa L. (family Zingiberaceae) is native to Southeast Asia and has a long history of therapeutic uses and a variety of important antimicrobial, antifungal, insecticidal, anti-inflammatory and antioxidant properties ( Khattak et al., 2005). Turmeric has been found effective for controlling mycelial growth of many fungi (Singh et al., 2002), and treatment of several diseases (Nostro et al., 2000).

\section{Material and Methods}

\subsection{Materials}

\section{(1) Broiler chicks}

The present study was carried on a total number of 120 apparent healthy unsexed Broiler chicks obtained from ElDakhelia Poultry Company.Broiler chicks were divided as the following: the first group: fed Broiler ration without any treatment (control group), the second group: Vaccinated with Gumboro. The third group : Fed with ration contain nigella sativa crushed seeds $1.5 \%$. The fourth group vaccinated with Gumboro and fed with ration contain nigella sativa crushed seeds $1.5 \%$. The fifth group: fed with ration contain curcumin powder $400 \mathrm{mg} / \mathrm{kg}$ diet. The sixth group vaccinated with Gumboro and fed with ration contain curcumin powder $400 \mathrm{mg} / \mathrm{kg}$ diet.

\section{Diet \& Management}

Chicks were kept at the Animal House ofEl_Mansoura Veterinary Medicine for 30 days of experiment. The chicks were randomly divided into six groups. Each treatment group contained 20 chicks.According to Hassan et al., (2003) chicks were housed in wire battery cages of $86 \mathrm{~L} \times 50$ $\mathrm{W} \times 25 \mathrm{H} \mathrm{cm}$ which were equally partitioned into 3 pens $(29 \times 50 \times 25 \mathrm{~cm})$. The batteries were provided with feeders and drinker equipment, the chicks were allowed libitum access 


\section{International Journal of Science and Research (IJSR) \\ ISSN (Online): 2319-7064 \\ Index Copernicus Value (2013): 6.14 | Impact Factor (2015): 6.391}

to feed and water.Ventilation and temperature $\left(22^{\circ} \mathrm{C}-31^{\circ} \mathrm{C}\right)$ were controlled to maintain bird comfort during the growout. Room were electrically heated and conditions of constant light were employed, provided 24 hours of lighting and checked three times daily for food, water and mortality.

\subsection{Basal Experimental Diet}

Diet was formulated to meet the nutritional requirements as suggested by the (NRC, 1994), to contain 24\% CP and 2900 $\mathrm{kcal} \mathrm{ME} / \mathrm{kg}$.Fresh feed were mixed weekly and not stored for more than one week. Neither antibiotic growth promoters nor anti-coccidials were added to any of the experimental diets.

\begin{tabular}{|c|c|}
\hline Ingredient & $\begin{array}{c}\text { Concentration } \\
(\mathrm{kg} / \text { 100kg diet })\end{array}$ \\
\hline Ground yellow corn & 55.780 \\
\hline Soya bean meal & 31.960 \\
\hline Fish meal & 1.000 \\
\hline Corn gluten & 7.450 \\
\hline Bran & 1.000 \\
\hline DicalciumPhosphate(22\%Ca\&19\%P) & 0.710 \\
\hline Limeston(38\% Ca) & 1.300 \\
\hline Lysine (purity 98\%) & 0.170 \\
\hline DL - Methionine (purity 98\%) & 0.070 \\
\hline Iodized sodium chloride & 0.300 \\
\hline Mineral\& Vitamin premix & 0.300 \\
\hline
\end{tabular}

The components of Basal experimental diet

Nigella sativa powder was purchased from Isis Company Registration No: COAE-Proc. COAE: Accreditation Certificate No.: DAKKs.ZE3307.00.According to Weiss (2002). The seeds contain about $35 \%$ carbohydrates, $21 \%$ protein and $35-38 \%$ fats. These fats are both saturated and unsaturated fatty acids and are present in oil in the following percentages: Saturated acids $18.1 \%$,monounsaturated acids $23.8 \%$, polyunsaturated acids $58.1 \%$, other minerals present in the seed include thiamin, niacin, calcium, folacin, zinc and phosphorus. The main component in nigella sativa is thymoquinone. It contains up to $50 \%$ of this phytochemical compound, which has antioxidant properties. It also contains about $40 \%$ p-cymene and 15\% a-pinene; naturally occurring organic compounds, as well as small amounts of other constituents. Nigella sativa was added freshly crushed every week to the feed in a dose $1.5 \%$ till the end after 30 days of the experement according to the plane of the work according to (Boka, et al., 2013 and Tahan\&Bayram 2011). Curcumin powder (C21H20O6) . Molecular weight 368.39, Molecular Formula: 1, 6heptadiene-3,5-dione-1,7-bis(4-hydroxy-3-methoxyphenyl)(1E,6E) or diferuloylmethane.
The components of Curcumin

\begin{tabular}{|c|c|}
\hline Volatile (essential) oils & $3-7 \%$ \\
\hline Fiber & $2-7 \%$ \\
\hline Mineral matter & $3-7 \%$ \\
\hline Protein & $6-8 \%$ \\
\hline Fat & $5-10 \%$ \\
\hline Moisture & $6-13 \%$ \\
\hline Carbohydrates & $60-70 \%$ \\
\hline
\end{tabular}

It was purchased from Research Lab Company imported from India Batch No.557A110713, curcuminpowder was added to the diet in adose rate $400 \mathrm{mg} / \mathrm{kg}$ diet according to (Tarasub et al., 2012). All chicks were vaccinated by hot strian (IBD) vaccines produced by Ceva Company according to (Giambrone and Ronald 1986).

\section{Growth Performance Study}

All chicks were weighted weekly till the end of experiment.

\section{Sampling}

\section{a) Blood Sampling}

Two blood samples were collected after slaughter. The first one was collected in EDTA tubes to prevent blood coagulation and used for determination of total leucocytic count and differential leucocytic count. The second blood sample was collected into aclean and dry screw capped centrifuge tubes without anticoagulant and left to clot at room temperature, then centrifuged at 3000 r.p.m for collection of clear serum sample used for the biochemical analysis of serum total protein,serum albumin, serum globulin,serum liver enzymes (AST and ALT), kidney function( creatinine and uric acid).

\section{b) Tissues Sampling}

After the chicks were slaughtered liver tissue were separated then washed with normal saline for determination of Superoxide dismutase (SOD)activity according to(Nishikimi et al., 1972)., reduced glutathione (GSH)according toAnderson (1985) and Bartels (1971), Catalase (CAT)according toAebi (1984), and Malondialdhehyde MDA content according to(Satoh, 1978)).

\section{Blood parameters}

Total leucocytic counts were performed using the improved Neubauer hemocytometer according to the method described by (Natt and Herrick., 1952). Determination of differential leucocytic count was performed using the method described by (Hoyer, 1993).

\section{Serum parameters}

Determination of serum total proteins according to (Doumas and and Biggs, 1971). Determination of serum albumin according to (Rodkey, 1965). Determination of serum liver function [Alanine Aminotransferase (ALT) andAspartate aminotransferase (AST)] according to(Murray, 1984).Determination of serum kidney function(uricacidand Creatinine) according toBartels, (1971).

\section{Results}




\section{International Journal of Science and Research (IJSR) \\ ISSN (Online): 2319-7064 \\ Index Copernicus Value (2013): 6.14 | Impact Factor (2015): 6.391}

Table 1: Effect of Nigllastaiva and Curcumin on the mean body weight in (g) in different groups

\begin{tabular}{|c|c|c|c|c|}
\hline Days & \multirow{2}{*}{ Adays Groups } & 14days & 21day & 30day \\
\hline G1(Control group). & $103 \pm 9.6^{\mathrm{a}}$ & $395 \pm 13.5^{\mathrm{b}}$ & $780 \pm 16.4^{\mathrm{b}}$ & $1080 \pm 19.7^{\mathrm{b}}$ \\
\hline Group2 ( Vaccinated group) & $101 \pm 8.5^{\mathrm{a}}$ & $309 \pm 14.2^{\mathrm{d}}$ & $635 \pm 14.3^{\mathrm{d}}$ & $935 \pm 18.4^{\mathrm{c}}$ \\
\hline Group3 ( Nigella sativa group) & $101.8 \pm 9.2^{\mathrm{a}}$ & $430 \pm 16.7^{\mathrm{a}}$ & $870 \pm 18.2^{\mathrm{a}}$ & $1160 \pm 22.4^{\mathrm{a}}$ \\
\hline Group4 (Vaccinated + nigella sativa group ) & $100 \pm 8.3$ & $379 \pm 14.7^{\mathrm{b}}$ & $755 \pm 15.6^{\mathrm{b}}$ & $998 \pm 20.6^{\mathrm{b}}$ \\
\hline Group5 (curcumin group) & $102 \pm 9.4$ & $401 \pm 15.2^{\mathrm{b}}$ & $830 \pm 16.4^{\mathrm{a}}$ & $1110 \pm 20.3^{\mathrm{b}}$ \\
\hline Group6 (Vaccinated + curcumin group) & $103 \pm 8.7$ & $358 \pm 15.4^{\mathrm{c}}$ & $695 \pm 14.2^{\mathrm{c}}$ & $1030 \pm 19.6^{\mathrm{b}}$ \\
\hline
\end{tabular}

Means with different letters in the same column are significantly different.

Table 2: Effect of Nigella Stiva and Curcumin on the differnetial cell count of different groups

\begin{tabular}{|c|c|c|c|c|c|c|}
\hline Groups & $\begin{array}{c}\text { Leucocyti c } \\
\text { count }\end{array}$ & Lymphocyte & Heterophils & monocyet & basophils & oesenophils \\
\hline Parameters & $34.60 \pm 1.7^{\mathrm{a}}$ & $59 \pm 3.6^{\mathrm{a}}$ & $33.4 \pm 2.9^{\mathrm{c}}$ & $3.8 \pm 0.2^{\mathrm{a}}$ & $0.9 \pm 0.04^{\mathrm{b}}$ & $3.5 \pm 0.2^{\mathrm{a}}$ \\
\hline Group1 (control group). & $25 \pm 1.3^{\mathrm{b}}$ & $47.55 \pm 2.9^{\mathrm{c}}$ & $45 \pm 3.2^{\mathrm{a}}$ & $2.9 \pm 0.1^{\mathrm{c}}$ & $1.4 \pm 0.1^{\mathrm{a}}$ & $2.85 \pm 0.2^{\mathrm{b}}$ \\
\hline Group2 (Vaccinated group) & $36.4 \pm 2.2^{\mathrm{a}}$ & $61.80 \pm 4.8^{\mathrm{a}}$ & $30 \pm 2.1^{\mathrm{c}}$ & $4.2 \pm 0.3^{\mathrm{a}}$ & $1.2 \pm 0.1^{\mathrm{a}}$ & $3.8 \pm 0.3^{\mathrm{a}}$ \\
\hline Group3 (Nigellasativa group) & $32 \pm 1.9^{\mathrm{a}}$ & $54.15 \pm 4.3^{\mathrm{a}}$ & $38.2 \pm 3.3^{\mathrm{b}}$ & $3.17 \pm 0.2^{\mathrm{b}}$ & $1.6 \pm 0.1^{\mathrm{a}}$ & $2.88 \pm 0.2^{\mathrm{b}}$ \\
\hline Group4 (Vaccinated + nigella sativa group ) & $32.40 \pm 1.6^{\mathrm{a}}$ & $59.80 \pm 3.9^{\mathrm{a}}$ & $32.6 \pm 2.7^{\mathrm{c}}$ & $3.9 \pm 0.3^{\mathrm{a}}$ & $1.2 \pm 0.1^{\mathrm{a}}$ & $2.95 \pm 0.2^{\mathrm{b}}$ \\
\hline Group5 (curcumin group) & $27.5 \pm 1.8^{\mathrm{b}}$ & $52.60 \pm 3.2^{\mathrm{b}}$ & $39.5 \pm 3.3^{\mathrm{b}}$ & $3.73 \pm 0.2^{\mathrm{a}}$ & $1.3 \pm 0.1^{\mathrm{a}}$ & $2.87 \pm 0.2^{\mathrm{b}}$ \\
\hline Group6 (Vaccinated + curcumin group)
\end{tabular}

Means with different letters in the same column are significantly different.

Table 3: Effect of Nigella Stiva and Curcumin on the serum biochemical parameters of different groups

\begin{tabular}{|c|c|c|c|c|c|c|c|}
\hline Parameters & $\begin{array}{c}\text { Total } \\
\text { protein(g/dl) }\end{array}$ & Albumin(g/dl) & Globulin(g/dl) & ALT(U/ l ) & AST(U/ l) & Criatinine(g/dl) & $\begin{array}{c}\text { Uric } \\
\text { acid(g/dl) }\end{array}$ \\
\hline Groups & $4.72 \pm 0.32^{\mathrm{b}}$ & $2.20 \pm 0.12^{\mathrm{b}}$ & $2.52 \pm 0.20^{\mathrm{b}}$ & $18.74 \pm 0.68^{\mathrm{b}}$ & $175 \pm 9.54^{\mathrm{b}}$ & $0.33 \pm 0.02^{\mathrm{b}}$ & $2.6 \pm 0.02^{\mathrm{b}}$ \\
\hline $\begin{array}{c}\text { Group1(Control group) } \\
\text { Group2(Vaccinated } \\
\text { group) }\end{array}$ & $3.6 \pm 0.22^{\mathrm{c}}$ & $1.83 \pm 0.07^{\mathrm{c}}$ & $1.77 \pm 0.15^{\mathrm{d}}$ & $32.11 \pm 1.12^{\mathrm{a}}$ & $203 \pm 10.2^{\mathrm{a}}$ & $1.08 \pm 0.05^{\mathrm{a}}$ & $3.9 \pm 0.04^{\mathrm{a}}$ \\
\hline $\begin{array}{c}\text { Group3( Nigella sativa } \\
\text { group) }\end{array}$ & $5.22 \pm 0.42^{\mathrm{a}}$ & $2.51 \pm 0.15^{\mathrm{a}}$ & $2.71 \pm 0.27^{\mathrm{a}}$ & $15.43 \pm 0.62^{\mathrm{b}}$ & $154 \pm 9.73^{\mathrm{c}}$ & $0.22 \pm 0.02^{\mathrm{b}}$ & $2.0 \pm 0.01^{\mathrm{b}}$ \\
\hline $\begin{array}{c}\text { Group4( Vaccinated + } \\
\text { nigella sativa group) }\end{array}$ & $4.49 \pm 0.28^{\mathrm{b}}$ & $2.05 \pm 0.09^{\mathrm{bc}}$ & $2.44 \pm 0.19^{\mathrm{bc}}$ & $23.24 \pm 1.04^{\mathrm{ab}}$ & $186 \pm 11.6^{\mathrm{b}}$ & $0.65 \pm 0.04^{\mathrm{b}}$ & $2.8 \pm 0.02^{\mathrm{b}}$ \\
\hline $\begin{array}{c}\text { Group5(curcumin } \\
\text { group) }\end{array}$ & $4.96 \pm 0.26^{\mathrm{b}}$ & $2.17 \pm 0.06^{\mathrm{b}}$ & $2.79 \pm 0.02^{\mathrm{b}}$ & $16.33 \pm 0.9^{\mathrm{b}}$ & $169 \pm 13.5^{\mathrm{b}}$ & $0.28 \pm 0.3^{\mathrm{b}}$ & $2.2 \pm 0.02^{\mathrm{b}}$ \\
\hline $\begin{array}{c}\text { Group6(Vaccinated }+ \\
\text { curcumin group }\end{array}$ & $4.12 \pm 0.34^{\mathrm{bc}}$ & $1.98 \pm 0.05^{\mathrm{bc}}$ & $2.14 \pm 0.29^{\mathrm{c}}$ & $26.54 \pm 1.04^{\mathrm{a}}$ & $191 \pm 15.4^{\mathrm{ab}}$ & $0.78 \pm 0.04^{\mathrm{b}}$ & $3.1 \pm 0.03^{\mathrm{b}}$ \\
\hline
\end{tabular}

Means with different letters in the same column are significantly different.

Table 4: Effect of Nigella Stiva and Curcumin on the liver tissue enzymatic antioxidantand non-enzymatic antioxidant system parameters of different groups

\begin{tabular}{|c|c|c|c|c|c|c|}
\hline Parameters & $\begin{array}{c}\text { Total } \\
\text { glutathione } \\
\text { ng/g tissue }\end{array}$ & $\begin{array}{c}\text { Reduced } \\
\text { glutathione } \\
\text { ng/g tissue }\end{array}$ & $\begin{array}{c}\text { Oxidized } \\
\text { glutathione } \\
\text { ng/g tissue }\end{array}$ & $\begin{array}{c}\text { Sodium oxide } \\
\text { dismutase U/g } \\
\text { tissue }\end{array}$ & $\begin{array}{c}\text { Malondialdehyde } \\
\text { MDA (M mol/g } \\
\text { tissue }\end{array}$ & $\begin{array}{c}\text { Ctalase U/g } \\
\text { tissue }\end{array}$ \\
\hline Groups & $6.10 \pm 0.50^{\mathrm{a}}$ & $5.77 \pm 0.44^{\mathrm{b}}$ & $0.33 \pm 0.06^{\mathrm{c}}$ & $14.56 \pm 0.67^{\mathrm{a}}$ & $39.56 \pm 2.32^{\mathrm{c}}$ & $15.02 \pm 0.48^{\mathrm{b}}$ \\
\hline $\begin{array}{c}\text { Group1 } \\
\text { (Control roup). }\end{array}$ & $3.18 \pm 0.09^{\mathrm{c}}$ & $2.36 \pm 0.07^{\mathrm{d}}$ & $0.82 \pm 0.02^{\mathrm{a}}$ & $8.78 \pm 0.45^{\mathrm{d}}$ & $61.43 \pm 4.65^{\mathrm{a}}$ & $10.13 \pm 0.55^{\mathrm{d}}$ \\
\hline $\begin{array}{c}\text { Group2 } \\
\text { (Vaccinated group) }\end{array}$ & $6.91 \pm 0.40^{\mathrm{a}}$ & $6.63 \pm 0.37^{\mathrm{a}}$ & $0.28 \pm 0.03^{\mathrm{c}}$ & $15.82 \pm 0.75^{\mathrm{a}}$ & $36.89 \pm 3.2^{\mathrm{c}}$ & $17.21 \pm 0.96^{\mathrm{a}}$ \\
\hline $\begin{array}{c}\text { Group3 } \\
\text { ( Nigella sativa group) }\end{array}$ & $4.82 \pm 0.30^{\mathrm{b}}$ & $4.34 \pm 0.26^{\mathrm{c}}$ & $0.48 \pm 0.04^{\mathrm{b}}$ & $14.89 \pm 0.54^{\mathrm{a}}$ & $45.3 \pm 0.43^{\mathrm{b}}$ & $13.54 \pm 0.65^{\mathrm{c}}$ \\
\hline $\begin{array}{c}\text { Group4 } \\
\text { (Vaccinated + nigella sativa group) }\end{array}$ & $6.27 \pm 0.40^{\mathrm{a}}$ & $5.96 \pm 0.37^{\mathrm{b}}$ & $0.31 \pm 0.03^{\mathrm{c}}$ & $12.87 \pm 0.64^{\mathrm{b}}$ & $38.24 \pm 2.30^{\mathrm{c}}$ & $15.82 \pm 0.73^{\mathrm{b}}$ \\
\hline Group5 (curcumin group) \\
\hline $\begin{array}{c}\text { Group6 } \\
\text { (Vaccinated + curcumingroup ) }\end{array}$ & $4.52 \pm 0.30^{\mathrm{b}}$ & $3.94 \pm 0.26^{\mathrm{c}}$ & $0.58 \pm 0.04^{\mathrm{b}}$ & $11.12 \pm 0.43^{\mathrm{c}}$ & $49.77 \pm 3.48^{\mathrm{b}}$ & $12.31 \pm 0.57^{\mathrm{c}}$ \\
\hline
\end{tabular}

Means with different letters in the same column are significantly different.

\section{Discussion}

Herbal medicine or herbalism (Nigella sativa and curcumin) is a time-honored practice of natural medicine that is older than mankind itself. The practice of using traditional herbal medicine based therapy is nowadays gaining more attention worldwide in both human and animal health care systems. Among the livestock sectors, poultry production systems are the most intensively reared with developments especially in the areas of nutrition, disease control, immunomodulators, genetic improvement, management and organization of dietary requirements along with the pressure of increasing demand for poultry products as well as threats of emerging pathogens( Kuldeep et al., 2015). This study showed that vaccinated group $\mathrm{G} 2$ which received Gumboro vaccine was decrease in body weight when compared to control group 


\section{International Journal of Science and Research (IJSR) \\ ISSN (Online): 2319-7064 \\ Index Copernicus Value (2013): 6.14 | Impact Factor (2015): 6.391}

and other groups as shown in table (1), these results agreed with the findings of (Shehata et al., 2009 and Kuldeep et al., 2015.). Decreasing of growth rate by Gumboro vaccine may be due to disturbance of one or more basic metabolic processes (carbohydrate, lipid and or protein metabolism) in the liver and loss of appetite (Cheeke and Shull, 1985). In the present study the curcumin treated group G4 show increase in body weight when compared to vaccinated group G2 as shown in table (1) these result are agree with (Sharma et al., 2011), which explained that the coadministration with curcumin improve bodyweight.. Chicks of G2 showed lower leucocyte levels; evidently this may be due to a considerable decrease in lymphocyte count. This may be indicative of the deterioration of immune status in the chicks of this group in response to the effect of vaccineSharma et al., (2011).The elevation of the heterophil : lymphocyte ratio is a hematological indicator that animals are coping with chronic stress (Gross and Siegel, 1983). Induction of the hypothalamic-pituitary-adrenal axis has been shown not only to reduce the lymphocyte number but also to increase the number of neutrophils (Dhabhar et al., 1995). ), these results are confirmed with (Sharma et al., 2011).In the present study, vaccinated group G2 which received hot strian (IBD) vaccine showed decrease in total protein, albumin and globulin when compared to control non medicated group G1 as shown in table (3), in this work, nigella stiva and curcumin treated group G3, G4 respectively, shows increase in total protein and albumin when compared to vaccinated group G2 as shown in table (3), these finding are in agreement with ( El-Emam et al.,2011). these finding is supported by (Mohapatra et al., 2011 andAshour et al., 2011), For the present study vaccinated group G2 which received hot strian (IBD) vaccines,showed increase in ALT and AST when compared to control non medicated group G1 table (3). These result are in agreement with (Amiridumari et al., 2013; Selim et al., 2014). According to Ozer et al., (2008). The elevation of AST and ALT may be due to significantly changed the stability of the lysosomal membrane, leading to a disorder of hepatocyte permeability in the liver (Varior and Philip, 2012). Treatment with nigella stiva and curcumin showed marked recovery in vaccine treated chicks as shown previously, these finding is supported byEl-Agamy, (2010). Curcumin showed a significant hepatoprotective activity by lowering the levels of serum marker enzymes ALT and AST. Treatment with nigella stiva and curcumin almost completely abolished the increase of serum ALT activity and decreased AST activity suggesting that curcumin and nigella stiva could effectively inhibit induced liver cell injury. The serum level of Nigella Sativa treated group G3 showed decrease in creatinine and uric acid when compared to group G2 table (3)these finding are supported by (Al-Ghasham et al., 2008). It is obvious that administration of Nigella sativa may protect liver from free radical reactions (Mona et al., 2002). Creatine is synthesized in the liver, passes into circulation and is taken up almost entirely by skeletal muscle for conversion to creatine phosphate, and then both creatine and creatine phosphate are converted spontaneously into creatinine. Both are filtered at glomerulus. Although there may be some addtional secretion of creatinine by renal tubules, creatine is reabsorbed by the tubules at low plasma concentration. (MC Lauchlan, 1988). In the present study, curcumin treated group G4 show decrease in creatinine and uric acid when compared to vaccin treated group G2 as shown in table (3), these results are supported with (Manikandan et al., 2011) . Curcumin administration showed a significant decrease in the levels of serum creatinine and uric acid. The curative effect of curcumin on the kidney markers can be attributed to its antioxidant property as it has been found that reactive oxygen species may be involved in the impairment of glomerular filtration rate(GRF) (Hughes et al., 1996).Concerning the present study, Nigella Sativa treated group G3 and curcumin treated G5 show an increase in SOD, GSH and CAT activity when compared to vaccinated group G2 as shown in table (4) and was decrease in MDA as shown in table (4), these finding were in agreement with (Kanter et al., 2006) which found NS treatment decreased tissue and prevent inhibition of superoxide dismutase (SOD), reduced glutathione (GSH), and catalase (CAT) enzyme (Nili-Ahmadabadi et al., 2011), that found treatment by NS at doses of significantly prevented MDA production index of lipid peroxidation.Moreover, AzevedoMartins et al., (2003) stated that SOD plays a role in the suppression of oxygen free-radical formation, SOD indicate that lipid peroxidation is one of the most prominent factors in carcinogenicity (Rastogi et al., 2001).Burits and Bucar, (2000) reported that NS acts as a donating agent in the DPPH assay and possesses hydroxyl radical scavenging properties in both the assay for non-enzymatic lipid peroxidation and the deoxyribose test. Nigella sativa oil also protect lipids against free-radical damage and may actually accelerate damage to other molecules (Burits and Bucar, 2000). Thymoquinone, the main compound in NS oil, inhibits non-enzymatic lipid peroxidation in liposomes. In addition to thymoquinone, there are many other compounds in the oil possessing a strong antioxidative effect, such as pcymene, m-cymene, $\alpha$-thujene and carvacrol, which have been reported to possess antioxidant effects and radical scavenging properties (Burits and Bucar, 2000). Nigella sativa has been encountered among the hepatoprotective herbs. Its active constituent TQ, considered as a potent antioxidant (Soliman et al., 2012), NS preserve the natural antioxidants in the cells by scavenging the superoxide anions (Badary et al., 2003). Current study show that curcumin treated group G4 show increase in SOD ,GSH and CAT activity when compared to vaccine treated group G2 as shown in table (4), this results are in agreement with ((Sharma et al., 2005 ; Mahmoud, 2013) which reported that curcumin increased the activities of both serum and liver tissue SOD and GSH, and decrease in MDA when compared to vaccine treated group G2 as shown in table (4), these results are in agreement with (Mahmoud, 2013).The antioxidant enzymes superoxide dismutase and catalase play an important role in keeping homeostasis and protection against oxidative damage by removing the free radicals (Jia et al., 2009)

\section{Conclusion}

We conclude that,IBD vaccine treatment resulted in haematological and biochemical changes typical of those reported previously. Treatment with Nigella sativa or Curcumin to chicks resulted in the restoration of the different parameters tested. The protective effects of Nigella sativa seeds may be due to the radical scavenging activity of

\section{Volume 5 Issue 8, August 2016}




\section{International Journal of Science and Research (IJSR) \\ ISSN (Online): 2319-7064}

Index Copernicus Value (2013): 6.14 | Impact Factor (2015): 6.391

its components, whereas the protective effects of Curcumin may be due to the phenolic compounds present in it,. Consequently, NS and Curcumin are quite useful and reasonable during using Gumboro vaccine and during Gumboroinfection.particularly the immunosuppressive ones, safeguard poultry health and boost the productive performance of birds. It has been vivid also that the potential of medicinal herbs as the valuable source of therapeutics aids has attained a global significant place in the health system. So the sustainable present and future of poultry sector necessitates the optimum and accurate implementationof herbal remedies which overcome the demerits of extensive allopathic drugs.

\section{References}

[1] Abdel-Rahman, O. ; Aini, I.; Mohd,H. B.and Kong,L.L. (2007): Differetiating strains of Gumboro disease . FRSA, ABIM Home page Technology News 19-36 GMT.

[2] Aebi, H. (1984):"catalase in vitro". Methods enzymol. 105: 121-126.

[3] Al-Ghamdi, M. S. (2001): The anti-inflammatory, analgesic and antipyretic activity of Nigella sativa. Journal of Ethnopharmacology. 76: 45-48.

[4] Al-Ghasham, A.; Ata, H. S.; El-Deep, S.; Meki, A. R. \&Shehada, S. (2008): Study of Protective effect of Date and Nigella sativa on Aflatoxin B1 Toxicity.International journal of health sciences. 2(2): 26.

[5] Aljabre, S. H. M.; R\&hawa, M. A.; Akhtar, N.; Alakloby, O. M.; Alqurashi, A. M. \&Aldossary, A. (2005):Antidermatophyteactivityof ether extract of Nigella sativa and its active principle, thymoquinone. Journal of Ethnopharmacology. 101:116-119.

[6] Amiridumari, H.; Sarir, H.; Afzali, N. \&FaniMakki, O. (2013): Effects of milk thistle seed against aflatoxin B1 in broiler model. Journal of research in medical sciences: the official journal of Isfahan University of Medical Sciences. 18(9): 786-792.

[7] Anderson M.E. (1985) : Determination of glutathione and glutathione disulphide in biological samples. Method Enzymol. 113:548-551.

[8] Ashiq, S.; Hussain, M. \& Ahmad, B. (2014): Natural occurrence of mycotoxins in medicinal plants: a review. Fungal genetics and Biology. 66: 1-10.

[9] Ashour, I. ;El-Ghnnam, A .; Abeer,G. A.;Dalia,M. H. ; and Aisha,I.E.(2011):Biochemical and Serological studies on the protective effect of black seed in experimentally infected broiler with Gumboro. AssiutVet.Med.J. Vol.57No. 131:441-462.

[10] Azab, A. E. S.; Fetouh, F. A. \&Albasha, M. O. (2014): Nephro-protective effects of curcumin, rosemary and propolis against gentamicin induced toxicity in guinea pigs: MorpholBiochem Study. Am. J. Clin. Experim. Med. 2: 28-35.

[11] Azevedo-Martins, A. K.; Lortz, S.; Lenzen, S.; Curi, R.; Eizirik, D. L. \&Tiedge, M. (2003): Improvement of the mitochondrial antioxidant defense status prevents cytokine-induced nuclear factor-kappaB activation in insulin-producing cells. Diabetes. 52: 93-101

[12] Badary, O. A.; Taha, R. A.; Gamal-EL Din, A. M. \& Abel-Wahab, M. H. (2003): Thymoquinone is a potent superoxide anion scavenger. Drug. Chem. Toxicol. 26: 87-98.

[13] Bartels, H.(1971): Human GesellschattBiochemich. And diagnostic mbh. Max Plank Ring 21 D- 65205 Wiesbaden. Germany Method of Clin. Chim. Acta.32,81.

[14] Boka,j. Mahdavi, A. H. Samie A. and. Jahanian R.(2013): Effect of different levels of black cumin (Nigella sativa) on performance, intestinal Escherichia coli colonization and jejunal morphology in laying hens.Journal of Animal and Physiology and Animal Nutrination.98:373-383.

[15] Burits, M. \&Bucar, F. (2000): Antioxidant activity of Nigella sativa essential oil. Phytother. Res. 14: 323328.

[16] Cheeke P. K. and Shull, L. R. (1985): Natural Toxicants in Feeds and Poisonous Plants. Avi. Publishing Company. ING, Westport, Connecticut.

[17] Cosgrove, A.S. (1962): An apparently new disease of chicken avian nephrosis. Avian Disease . 6:385-389.

[18] Dhabhar, F. S.; Miller, A. H.; McEwen, B. S. \& Spencer, R. L. (1995): Effects of stress on immune cell distribution. Dynamics and hormonal mechanisms. J. Immunol. 154: 5511-5527.

[19] Doumas, B. T. \& Biggs, H. G. (1971): Determination of serum globulin. In: standard Methods of Clinical Chemistry, edited by G.R Copper, New York Academic Press. 7.

[20] EI Emam, K.; Jonker, E.; Arbuckle, L. \&Malin, B. (2011). A systematic review of reidentification attacks on health data. PloS one. 6 (12): 28071.

[21] El-Agamy, D. S. (2010): Comparative effects of curcumin \& resveratrol on aflatoxin B1-induced liver injury in rats. Archives of toxicology. 84(5): 389-396.

[22] El-Sergany, H.A. ; Saber, M.S., and Mohamed, M.A. (1974): Preliminary investigation on the occurrence of Gumboro in Egypt. Egypt J. Vet. Scin., 11: 7-11.

[23] Giambrone, J.J.; and Ronald,P.E. (1986): Vaccination of day old broiler chicks against Newcastle and infectious bursal disease using commercial live and lor inactivated vaccines. Avian Dis. , 30 (3):557-562.

[24] Gross, W. B. \& Siegel, H. S. (1983): Evaluation of the heterophil/lymphocyte ratio as a measure of stress in chickens. Avian Dis. 27: 972-979.

[25] Hassan, S. M.; Mady, M. E.; Cartwright, A. L.; Sabri, H. M. \&Mobarak, M. S. (2003): Effect of early feed restriction on reproductiveperformance in Japanese quail (Coturnixcoturnix japonica). Poult. Sci.82:11631169.

[26] Hoyer, J. D. (1993): Laboratory Med and pathology Leucocytic differential count. Mayo Clinic Prossiding. 68: 1027-1028.

[27] Hughes, A. K.; Stricklett, K.; Padilla, E. \&Kihan, D. E. (1996): Effect of reactive oxygen species on endothelin-1 production by human mesangial cells. Kidney Int. 49: 181-189.

[28] Jia, J.; Zhang, X.; Hu, y.; Wu, y. \& Wang, Q. (2009): Evaluation of in vivo antioxidants activities of Ganodermalucidum polysaccharides in STZdiabetic rats. Food Chern. 115: 32-36.

[29] Kanter, M.; Coskun, O.; Kalayci, M.; Buyukbas, S.; Cagavi, F.; (2006): Neuroprotective effects of Nigella 
sativa on experimental spinal cord injury in rats. Hum. Exp. Toxicol. 25: 127-133.

[30] Kanter, M.; Demir, H.; Karakaya, C. \&Ozbek, H. (2005): Gastroprotective activity of Nigella sativa L. oil and its constituent, thymoquinone against acute alcoholinduced gastric mucosal injury in rats. World Journal of Gastroenterology. 11: 6662-6666.

[31] Khan, M. A. U.; Ashfaq, M. K.; Zuberi, H. S.; Mahmood, M. S. \& Gilani, A. H. (2003): The in vivo antifungal activity of the aqueous extract from Nigella sativa seeds. Phytotherapy Research. 17(2): 183-186.

[32] Khattak, S.; Rehman, S.; Shah, H.U.; Ahmad, W. \& Ahmad M. (2005): Biological effects of indigenous medicinal plants Curcuma longa and Alpinia galangal. Fitoterapia. 76: 254-257.

[33] KuldeepDhama, S. K.; Latheef, S. M., Hari Abdul Samad, K.; Karthik, R.T.; Rifat U. K., Mahmoud A.; Mayada R. F.; Gazi M. A.; Vito L. and Vincenzo T. (2015): Multiple Beneficial Applications and Modes of Action of Herbs in Poultry Health and Production. International Journal of Pharmacology, 11: 152-176.

[34] Madbouly, H. M.; El-Sanousi, A. ; M.S. and Reda, I.M.(1992): Infectious bursal disease virus infection among Egyption poultry flocks. Vet. Med. J. Giza, 40 (2):55-62.

[35] Mahmoud, E. A. (2013): Effect of curcumin on hematological, biochemical and antioxidants parameters in Schistosoma mansoni infected mice. International Journal of Sciences. 2(3): 1-14.

[36] Manikandan, R.; Beulaja, M.; Thiagarajan, R.; Priyadarsini, A.; Saravanan, R. \&Arumugam, M. (2011): Ameliorative effects of curcumin against renal injuries mediated by inducible nitric oxide synthase and nuclear factor kappa B during gentamicin-induced toxicity in Wistar rats. European journal of pharmacology. 670(2): 578-585.

[37] Mc Lauchlan D. M. (1988): Creatinine, urate and urea. In: Varleysís Practical Clinical Biochemistry. Gowenlock, A. D. (ed.), Heinemann Medical Books, London. 350.

[38] Mohapatra, S.; Sahu, N. P.; Pal, A. K.; Prusty, A. K.; Kumar. V. \& Kumar, S. (2011): Haematoimmunology and histoarchitectural changes in Labeorohita fingerlings: effect of dietary aflatoxin and mould inhibitor. Fish Physiol. Biochem. 37: 177-186.

[39] Mona, S. Z.; Osfor, M. H.; Tohamy, A. \&Zytoun, E. M. (2002): Some Clinicopathologicaland Nutritional Studies on Reduction of Aflatoxin Induced Hepatotoxicity in Clariouslazara Catfish By Fax-Atoxin and Nigella sativa Oil. Egypt. J. Microbiol. 37(2): 185195.

[40] Morsi, N. M. (2000): Antimicrobial effect of crude extracts of Nigella sativa on multiple antibioticsresistant bacteria. Acta. MicrobiologicaPolonica. 49(1): 63-74.

[41] Murray R. (1984): Alanine aminotransferase. Clin. Chem. the C.V mosby Co. St Louis. Toronto. Princeton 1088- 1090 .

[42] Natt, M. P. \& Herrick, C. A. (1952): A new blood diluents for counting the erythrocytes and leucocytes of chickens. Poultry Sci. 31: 735-738.
[43] Nili-Ahmadabadi, A.; Tavakoli, F.; Hasanzadeh, G. R.; Rahimi, H. R. \&Sabzevari, O. (2011): Protective effect of pretreatment with thymoquinone against Aflatoxin B1 induced liver toxicity in mice. Daru: journal of Faculty of Pharmacy, Tehran University of Medical Sciences. 19(4): 282.

[44] Nishikimi, M.; Rao, N. A. \& Yogi, K. (1972): The occurance of super oxide anion in the reaction of reduced phenazinemethosulfate and molecular oxygen. Biochemical and Biophysical Research. Common, 46: $849-854$.

[45] Nostro, A.; Germano, M. P.; D'Angelo, V. \&Cannatelli, M. A. (2000): Extraction methods and bioautography for evaluation of medicinalplant antimicrobial activity. Letters in Applied Microbiology. 30: 279-284.

[46] NRC National Research Council (1994): Nutritional requirements of poultry". 9th Rev. Ed. National academy press, Washington, DC.

[47] Ozer, J.; Ratner, M.; Shaw, M.; Bailey, W. \&Schomaker, S. (2008): The current state of serum biomarkers of hepatotoxicity. Toxicology. 245: 194205.

[48] Rastogi, R.; Srivastava, A. K. \&Rastogi, A. K. (2001): Long term effect of aflatoxin B1 on lipid peroxidation in rat liver and kidney: effect of picroliv and silymarin. Phytother. Res. 15: 307-310.

[49] Rodkey, F. L. (1965): Clinical Chemistry. 11: 478-487.

[50] Rooney, S. \& Ryan, M. F. (2005): Effects of alphahederinandthymoquinone - a constituent of Nigella sativa, on human cancer celllines. Anticancer Research. 25: 2199-2204.

[51] Satoh, K. (1978):"Serum lipid peroxide in cerebrovascular disorders determined by a new colorimetric method.Clin. Chim. Acta. 90: 37.

[52] Selim, M.; El-hofy, H. \& Khalil, R. (2014): The efficacy of three mycotoxin adsorbents to alleviate aflatoxin B1-induced toxicity in Oreochromisniloticus. Aquacult. Int. 22: 523-540.

[53] Selim, M.; El-hofy, H. \& Khalil, R. (2014): The efficacy of three mycotoxin adsorbents to alleviate aflatoxin B1-induced toxicity in Oreochromisniloticus. Aquacult. Int. 22: 523-540.

[54] Sharma, R. A.; Gescher, A. J. \& Steward, W. P. (2005): Curcumin: the story so far. European journal of cancer. 41(13): 1955-1968.

[55] Sharma, V.; Sharma, C.; Paliwal, R.; Pracheta, S. S. \& Sharma, S. (2011): Ameliorative effects of Curcuma longa and curcumin on aflatoxin B1 induced serological \& biochemical changes in kidney of male mice. Asian $\mathrm{J}$. Biochem. Pharmaceut. Res. 2(1): 338-351.

[56] Shehata, S. A.; El-Melegy, Kh. M.; Ebrahim, M. S. \&Abou- Seif, R. A. (2009): Aflatoxin B1 Toxicity Reduction by Tafla Clay, Honey and Nigella Sativa Addition in Fish. Journal of the arabian aquaculture society. 4(1): 55-72.

[57] Shishodia, S.; Sethi, G. \& Aggarwal, B. B. (2005): Curcumin: getting back to the roots. Annals of the New York Academy of Sciences. 1056(1): 206-217.

[58] Singh, G.; Singh, O. P. \&Maurya, S. (2002): Chemical and biocidal investigations on essential oils of some Indian Curcuma species Progress in Crystal Growth and Characterization of Materials. 45: 75-81. 


\section{International Journal of Science and Research (IJSR) \\ ISSN (Online): 2319-7064}

Index Copernicus Value (2013): 6.14 | Impact Factor (2015): 6.391

[59] Soliman, G.; Hashem, A. \&Arafa, M. (2012): Protective Effect of Curcuma Longa or Nigella Sativa on Aflatoxin B1-Induced Hepato-Toxicity in Rats in Relation to Food Safety on Public Health. The Medical Journal of Cairo University. 80(2).

[60] Tahan, M. \&Bayram, I. (2011): Effect of using black cumin (Nigella sativa) and parsley (Petroselinum crispum) in laying quail diets on egg yield, egg quality and hatchability. ArchivaZootechnica. 14(4): 39-44.

[61] Tarasub, N.; Junseecha, T.; Tarasub, C.; \& Ayutthaya, W. D. N. (2012): Protective effects of curcumin, vitamin $\mathrm{C}$, or their combination on cadmiuminduced hepatotoxicity. Journal of basic and clinical pharmacy. 3(2):273

[62] Varior, S. \& Philip, B. (2012): Aflatoxin B1 induced alterations in the stability of the lysosomal membrane in Oreochromismossambicus (Peters 1852). Aqua. Res. 43(8):1170-1175.

[63] Weiss, E. A. (2002): Spices Crops. CABI. Wallingford. 356-360. 